\title{
Characterization of extracellular polymeric substances (EPS) from periphyton using liquid chromatography-organic carbon detection-organic nitrogen detection (LC-OCD-OND)
}

\author{
Theodora J. Stewart • Jacqueline Traber • \\ Alexandra Kroll • Renata Behra • Laura Sigg
}

Received: 2 July 2012 / Accepted: 24 September 2012 /Published online: 12 October 2012

(C) The Author(s) 2012. This article is published with open access at Springerlink.com

\begin{abstract}
A protocol was developed to extract, fractionate, and quantitatively analyze periphyton extracellular polymeric substances (EPS), which obtains both information on the molecular weight $\left(M_{\mathrm{r}}\right)$ distribution and protein and polysaccharide content. The EPS were extracted from freshwater periphyton between July and December 2011. Organic carbon (OC) compounds from different EPS extracts were analyzed using liquid chromatography-organic carbon detection-organic nitrogen detection (LC-OCD-OND), and total protein and polysaccharide content were quantified. Four distinct OC fractions, on the basis of $M_{\mathrm{r}}$, were identified in all extracts, corresponding to high $M_{\mathrm{r}}$ biopolymers $(\geq 80-4 \mathrm{kDa})$, degradation products of humic substances ( $M_{\mathrm{r}}$ not available), low $M_{\mathrm{r}}$ acids $(10-0.7 \mathrm{kDa})$, and small amphiphilic/neutral compounds (3-0.5 kDa). Low $\mathrm{C} / \mathrm{N}$ ratios $(4.3 \pm 0.8)$ were calculated for the biopolymer fractions, which represented $16-38 \%$ of the measured dissolved organic carbon (DOC), indicating a significant presence of high $M_{\mathrm{r}}$ proteins in the EPS. Protein and polysaccharide represented the two major components of EPS and, when combined, accounted for the measured DOC in extracts. Differences in specific OC fractions of EPS extracts over the course of the
\end{abstract}

Responsible editor: Philippe Garrigues

Electronic supplementary material The online version of this article (doi:10.1007/s11356-012-1228-y) contains supplementary material, which is available to authorized users.

T. J. Stewart $\cdot$ J. Traber $\cdot$ A. Kroll $\cdot$ R. Behra $\cdot$ L. Sigg $(\triangle)$

Eawag, Swiss Federal Institute of Aquatic Science

and Technology,

8600 Dübendorf, Switzerland

e-mail: laura.sigg@eawag.ch

T. J. Stewart $•$ L. Sigg

ETH, Institute of Biogeochemistry and Pollutant Dynamics IBP,

8092 Zurich, Switzerland study could be quantified using this method. This study suggests that LC-OCD-OND is a new valuable tool in EPS characterization of periphyton.

Keywords Periphyton · Biofilm · EPS · Characterization · LC-OCD-OND $\cdot$ Polysaccharide $\cdot$ Protein

\section{Introduction}

Phototrophic biofilms, also commonly referred to as periphyton, are communities of hetero- and autotrophic organisms held together by a network of extracellular polymeric substances (EPS). The excreted EPS, typically composed of polysaccharides, proteins, glycoproteins, glycolipids, nucleic acids, and amphiphilic compounds (Cogan and Keener 2004; Neu and Lawrence 2009; Stoodley et al. 2002), provide both biofilm structure and a nutrient source for periphytic organisms, but also may serve as a protective barrier against toxic compounds, such as nonessential trace metals.

Methods of EPS characterization have largely relied on techniques for quantification of total proteins and polysaccharides in EPS, using assays, such as the Bradford and Lowry, and the DuBois methods (Bradford 1976; DuBois et al. 1956). Despite the relative ease of standard assays, these methods only provide information on total concentrations in a sample. More detailed characterization techniques, such as HPLC, have been used to determine the monosaccharide composition in both bacterial and phototrophic biofilms (Celik et al. 2008; Congestri 2006; Meisen et al. 2008), coupled mass spectrometry (MS) techniques, such as LCMS/MS, have been used to identify specific proteins in bacterial biofilms (Cao et al. 2011), and confocal scanning laser microscopy has been used to study the exopolysaccharide composition of biofilms using fluorescently labeled 
lectins (Zippel and Neu 2011). These methods have the advantage of targeting and identifying specific types of extracellular compounds. However, what is needed is a comprehensive and quantitative approach, able to simultaneously fractionate and characterize EPS.

Liquid chromatography-organic carbon detection-organic nitrogen detection (LC-OCD-OND) is a technique based on size-exclusion chromatography (SEC), which is able to provide quantitative information regarding organic carbon (OC) compounds, such as polysaccharides and proteins found in EPS. Although SEC has been previously used for the separation of compounds in bacterial EPS (Ras et al. 2011; Simon et al. 2009; Villain et al. 2010), LC-OCD-OND provides additional information by the online coupling of SEC to OC, organic nitrogen (ON), and ultraviolet (UV) detectors. The total (TOC) and dissolved organic carbon (DOC) are measured, and DOC is further separated and quantified in six separate fractions: biopolymers (high $M_{\mathrm{r}}$ polysaccharides and proteins), humic substances (HS), building blocks of HS, low $M_{\mathrm{r}}$ acids, and amphiphilic/neutral compounds (alcohols, aldehydes, ketones, and amino acids). This technique has been used in the drinking and groundwater monitoring sectors, and there is a collection of work that has studied different fractions of EPS from bacterial biofilms, with respect to assessing membrane fouling (Al-Halbouni et al. 2008; Meng et al. 2009; Zheng et al. 2009). However, LC-OCD-OND has never been used as a tool to characterize EPS from periphyton.

The aim of this work was twofold: to develop an extraction protocol for EPS from periphyton suitable for metal analysis and to obtain $M_{\mathrm{r}}$ and protein and polysaccharide content of different OC fractions of EPS using LC-OCD-OND. The EPS was extracted from biofilms, colonized between July and December 2011. Chromatograms from this 6-month period were compared to determine if differences in EPS composition could be observed and quantified using this technique. Results were compared with total polysaccharide and protein quantification. The application of LC-OCD-OND for the characterization of periphyton EPS is assessed.

\section{Materials and methods}

\section{Periphyton colonization}

All periphyton was colonized on glass microscope slides, previously acid soaked in $0.03 \mathrm{M} \mathrm{HNO}_{3}$ and washed with nanopure water ( $\Omega 18$, Milli-Q), which were placed in Plexiglas flow-through channels with continuous pumping of natural stream water from the Chriesbach (Dübendorf, Switzerland) (Navarro et al. 2008). Each channel contained four rows of eight paired glass slides $(76 \times 26 \mathrm{~mm}$, Thermo Scientific), amounting to a total of 64 slides per channel.
Larger-sized sediment was removed from the water before entering colonization channels by using a sediment trap $(51 \times 70 \times 260 \mathrm{~cm})$ with an average residence time of $20 \mathrm{~min}$. Flow rate was maintained at approximately $1 \mathrm{~cm} / \mathrm{s}$ and monitored with a Schildknecht MiniAir2 flow meter. Illumination was provided by BioSun fluorescent tubes (MLT Moderne Licht-Technik AG, ML-T8 36W/965/ G13B), mimicking the natural sunlight spectrum. Light/dark cycles, each $12 \mathrm{~h}$, were maintained with electronically controlled timers (Demelectric AG). Slides were transferred to a plastic box containing stream water, so that drying of the biofilms was avoided during transport, prior to extraction.

\section{Periphyton EPS extraction}

Glass slides were taken from flow-through channels after 25 days of colonization. Biomass was gently scraped off with a clean glass slide into a $100-\mathrm{mL}$ muffled glass beaker placed on ice containing the extraction solution composed of $\mathrm{NaNO}_{3}(10 \mathrm{mM}, \mathrm{pH} 7.4)$ and a $1-\mu \mathrm{g} / \mathrm{mL}$ protease inhibitor cocktail, with equal amounts of Aprotinin, Leupeptin, and Pepstatin A (AppliChem AG). The $10-\mathrm{mM} \mathrm{NaNO}_{3}$ was chosen, as it is a chemically inert salt with an ionic strength similar to the stream water used to colonize the periphyton. A volume of $60 \mathrm{~mL}$ was used for the extraction of 32 slides. The biofilm slurry was resuspended in the solution by gentle pipetting and then further resuspended using a water sonication bath ( $45 \mathrm{kHz} 60 \mathrm{~W}$, VWR Ultrasonic Cleaner) for $30 \mathrm{~s}$. Fine sediment and larger biomass was allowed to settle, and the solution was removed and centrifuged at $1,880 \times \mathrm{g}$ for $10 \mathrm{~min}$. Biomass was resuspended a second time in fresh solution and treated as described above. In a separate series of extractions, $\mathrm{NaHCO}_{3}(2 \mathrm{mM}, \mathrm{pH}$ 7.6) was used as an extraction solution.

To determine if agitation of the solution over time yielded higher EPS extraction efficiencies, two different physical methods were compared, referred to as shaking and stirring methods. A biofilm slurry was obtained according to the above protocol and a control sample, representing $t=0$, was taken before the remaining slurry was separated into separate aliquots. Half of the aliquots were placed on a shaker at $90 \mathrm{rpm}$, whereas the remaining aliquots were stirred at $300 \mathrm{rpm}$. Samples were taken after 30,60, 90, and $120 \mathrm{~min}$ from each type of extraction method and centrifuged at $1,880 \times \mathrm{g}$ for $10 \mathrm{~min}$. The resulting biomass pellet was lyophilized overnight, and dry weight measurements were taken. All supernatants were filtered through $0.22 \mu \mathrm{m}$ PES Millipore filters, which were previously flushed with $1 \mathrm{~L}$ of nanopure water ( $\Omega$ 18, Milli-Q) to prevent OC contamination of the sample. Filtered samples were stored in muffled $100-\mathrm{mL}$ glass Schott flasks at $4{ }^{\circ} \mathrm{C}$ and treated with a final concentration of $0.02 \%(w / v) \mathrm{NaN}_{3}$ to prevent bacterial growth and subsequent degradation of EPS. 
Glucose-6-phosphate dehydrogenase assay

Activity of glucose-6-phosphate dehydrogenase (G6P-DH), an intracellular enzyme, was measured in extracts according to Esposito et al., to determine the degree of cell lysis resulting from the extraction technique used in this study (Esposito et al. 2006). At each step of the extraction (i.e., scraping of biofilms from slides, sonication, centrifugation, and filtration), samples were taken in triplicate and transferred to a 96-well plate. Upon addition of $180 \mu \mathrm{L}$ of reaction mixture $(50 \mathrm{mM}$ Tris Base, $0.15 \mathrm{mM}$ NADP, $10 \mathrm{mM} \mathrm{MgCl}_{2}$, and $3 \mathrm{mM}$ glucose-6-phosphate), absorption of NADPH (formed during the conversion of glucose-6phosphate) was measured at $340 \mathrm{~nm}$ at $30{ }^{\circ} \mathrm{C}$ over $30 \mathrm{~min}$. A standard curve was generated using G6P-DH in both water and in the EPS extract to verify that the EPS did not interfere with the detection of G6P-DH activity. The limit of detection in both cases was $0.00125 \mathrm{U} / \mathrm{mL}$ ( $\mathrm{U}=$ the amount of enzyme that reduces $1.0 \mu \mathrm{mol} \mathrm{NADP} / \mathrm{min}$ at $30^{\circ} \mathrm{C}$, $\mathrm{pH}$ 7.8). To measure total activity of the biomass, cell lysis was induced by combining $1 \mathrm{~mL}$ of the biomass suspension with the same volume of extraction solution containing $0.1 \%$ SDS. The sample was sonicated for $15 \mathrm{~min}$, centrifuged, and the supernatant was used as a representation of total G6P-DH activity. A known amount of G6P-DH was also treated as described above to verify that the procedure did not inhibit G6P-DH activity.

\section{LC-OCD-OND characterization of extracted EPS}

To characterize the OC compounds found in the extracted EPS, LC-OCD-OND was used. Samples were diluted (1:50) with nanopure water $(\Omega 18$, Milli-Q) in muffled assimilable organic carbon-free $20-\mathrm{mL}$ glass vials. Compounds were separated using a size exclusion column $(250 \times 20 \mathrm{~mm}$, Toyopearl TSK HW-50S) able to separate both polysaccharides $(0.1-18 \mathrm{kDa})$ and proteins $(0.5-80 \mathrm{kDa}$ for globular proteins), as reported by the manufacturer. A handling control, in which the extraction solution was treated like the periphyton EPS extract, was performed to assess the carbon contamination associated with the extraction protocol. In all cases, OC coming from the handling control accounted for less than $2 \%$ of DOC in extracts and, therefore, was negligible for the quantification of OC compounds in EPS. Phosphate buffer ( $24 \mathrm{mM}, \mathrm{pH} 6.6)$ was used as the mobile phase and phosphoric acid solution $(60 \mathrm{mM}, \mathrm{pH} 1.2)$ was used as an acidification solution to aid in the removal of inorganic carbon prior to analysis. The limit of quantification was $10 \mu \mathrm{g} / \mathrm{L}$ for both OC and ON.

The TOC and DOC, as well as specific OC compounds, were identified and quantified using FIFFIKUS, a software quantification method (DOC-Labor Dr. Huber, Germany). Distinguishable fractions can include mineral colloids, polysaccharides, HS, building blocks of HS, low $M_{\mathrm{r}}$ acids, and amphiphilic/neutral compounds. The software uses information obtained from the isolation of polysaccharides, and other fractions from EPS, and their subsequent measurement using ion chromatography and amperometric detection for sugars.

\section{LC-OCD-OND calibration}

Protein and polysaccharide standards were measured to create a calibration curve for the $M_{\mathrm{r}}$ determination of peaks from extracts. BSA (66.5 kDa), ovalbumin $(44 \mathrm{kDa})$, Carbonic Anhydrase (29 kDa), Ribonuclease A (13.7 kDa), Aprotinin $(6.5 \mathrm{kDa})$, and Pepstatin A $(0.686 \mathrm{kDa})$ were used as protein standards. Thyroglobulin $(669 \mathrm{kDa})$ was used to determine the void volume of the column and for the calculation of retention factors. Protein standards were measured both individually and in mixtures in phosphate buffer, $\mathrm{NaNO}_{3}, \mathrm{NaHCO}_{3}$, and spiked in EPS extracts so as to rule out matrix effects on elution times. As no significant effects were observed, the standard calibration curve in phosphate buffer was used for $M_{\mathrm{r}}$ calculations (Online resource 1 in the Electronic supplementary material (ESM)). Mixtures of protein standards (Thyroglobulin $(669 \mathrm{kDa}), \mathrm{BSA}(66.5 \mathrm{kDa})$, Ovalbumin (44 kDa), and Pepstatin A (0.686 kDa)), corresponding to retention times of peaks seen in EPS extracts, were analyzed (Online resource 2 in the ESM) to determine the resolution of $M_{\mathrm{r}}$ separation in these mixtures. Polyethylene glycol (PEG) standards ranging from 0.106 to $21.030 \mathrm{kDa}$ were used as polysaccharide standards and measured in nanopure water $\left(\Omega 18\right.$, Milli-Q), $\mathrm{NaNO}_{3}$, $\mathrm{NaHCO}_{3}$, and spiked in EPS extracts. The standard calibration curve in nanopure water was used for $M_{\mathrm{r}}$ calculations.

Protein and polysaccharide quantification

The Bradford assay was conducted on the whole extract to quantify total protein (Bradford 1976). BSA was used for standard calibration, and extracts were diluted with nanopure water to fall within the calibration range. Bradford dye reagent (Bio-Rad) was used for the analysis. Absorbance was measured at $595 \mathrm{~nm}$, and samples were measured in triplicate. Protein was converted from micrograms of protein to milligrams of carbon, assuming an average carbon content of $0.53 \mathrm{~g} \mathrm{C} / \mathrm{g}$ protein (Rouwenhorst et al. 1991).

The phenol-sulfuric acid method (DuBois method) was used on the whole extract to determine total polysaccharide content (DuBois et al. 1956). Glucose was used as a calibration standard. Equal volumes of sample or glucose standard were mixed with phenol $(500 \mu \mathrm{L}, 2 \%(w / v)$, Fluka) in glass vials and then $2.5 \mathrm{~mL}$ of concentrated sulfuric acid (95-97\%, Sigma-Aldrich) was added, and the solution was mixed via gentle vortex. After allowing the sample to cool 
for $30 \mathrm{~min}$, absorbance of solutions was measured at $490 \mathrm{~nm}$. Polysaccharide was converted from micrograms of polysaccharide to milligrams of carbon, assuming $0.4 \mathrm{~g}$ C/g polysaccharide (Rouwenhorst et al. 1991).

\section{Results}

\section{Extraction method}

The EPS extraction efficiencies of the shaking and stir methods were evaluated with respect to TOC and DOC. The amount of extracted TOC and DOC are shown in Fig. 1 as a function of extraction time. No significant differences were observed between these two methods over the course of $120 \mathrm{~min}$ nor were differences observed over time within a single type of extraction technique. No differences were observed between $\mathrm{NaNO}_{3}$ and $\mathrm{NaHCO}_{3}$ as extraction solutions (Online resource 3 in the ESM). Results from the G6P-DH assay indicated no detectable G6P-DH activity during any step of the EPS extraction, as measurements were all below the limit of detection of the assay (Online resource 4 in the ESM).

\section{EPS characterization}

In all LC-OCD-OND chromatograms (Fig. 2a), four distinct fractions were observed corresponding to biopolymers, building blocks of HS, low $M_{\mathrm{r}}$ acids, and neutral/amphiphilic compounds. No HS were present in any EPS extracts measured, as HS typically elute at approximately $45 \mathrm{~min}$ and would display a distinct signal in the UV spectra (Huber et al. 2011). However, UV absorbance (254 nm) was observed for the biopolymer and low $M_{\mathrm{r}}$ acid fractions in all extracts (Online resource 5 in the ESM). An ON signal was measured for all biopolymer fractions (Fig. 2b) but could

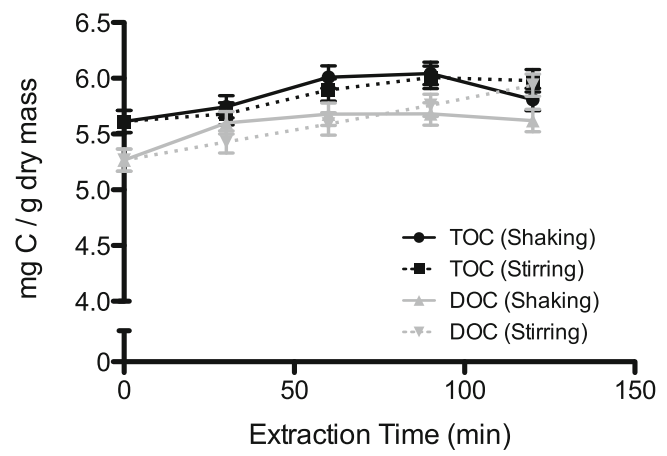

Fig. 1 OC extraction efficiency of shaking and stirring extraction methods. Biomass slurry from harvested biofilms was split into separate aliquots, and EPS was extracted either with shaking (solid line) or stirring (dashed line) methods over $120 \mathrm{~min}$ in triplicate. Samples were taken at different time points for analysis with LC-OCD-OND. Error bars generated from standard deviation of triplicates not be assessed for the other fractions as the nitrogen signal from $\mathrm{NaNO}_{3}$, which was detected at the same retention time as the remaining fractions, was too large. Areas of individual fractions were integrated as shown in Fig. 2a, quantified, and are presented as a percentage of chromatographable DOC (Fig. 3).

As seen in Fig. 3, the biopolymer fraction represented $16-38 \%$ of measured DOC, whereas the building block, low $M_{\mathrm{r}}$ acid, and neutral fractions corresponded to $16-25$, 5-8, and 40-60 \% DOC, respectively. Extract taken in July contained the least amount of biopolymers (16\% DOC) relative to the other $\mathrm{OC}$ fractions, whereas extracts from August and the beginning of November (6 November 2011) contained the largest amounts (38 and $37 \%$ DOC, respectively). A decreasing trend was observed between November and December. From the quantification of OC and $\mathrm{ON}$ in the biopolymer fractions, an average $\mathrm{C} / \mathrm{N}$ ratio of $4.3 \pm 0.8$ was calculated. The amount of building blocks varied less over the course of study, with the greatest amount found in the September extract. The low $M_{\mathrm{r}}$ acids were consistent throughout all extracts. The neutral/amphiphilic fraction corresponded to the greatest percentage of measured DOC in the EPS extracts. Similar amounts were quantified in extracts from August through early November (37-40\% DOC) and greater amounts were measured in extracts from July (60\% DOC), November (19 November 2011; $49 \%$ DOC) and December (53\% DOC) (Fig. 3).

Calculated ranges of $M_{\mathrm{r}}$ for each fraction, using protein and polysaccharide-generated standard curves, are shown in Table 1 . The $M_{\mathrm{r}}$ range of proteins in the biopolymer fraction was 12 to $\geq 80 \mathrm{kDa}$, whereas polysaccharides fell between 4 to $\geq 20 \mathrm{kDa}$. The low $M_{\mathrm{r}}$ acid fraction corresponded to a peptide range between 2 and 10 and 0.7 and $3 \mathrm{kDa}$ for polysaccharides. Neutral/amphiphilic compounds corresponded to 0.5-3 kDa. The $M_{\mathrm{r}}$ of the building blocks fraction was not calculated because there were no distinct peaks corresponding to this fraction for which a $M_{\mathrm{r}}$ range could be calculated.

Differences between EPS extracts obtained in replicate, taken from the same set of biofilms harvested from one channel, was less than $20 \%$ for biopolymers and building blocks and less than $10 \%$ for low $M_{\mathrm{r}}$ acid and neutral/ amphiphilic fractions (Online resource 6 in the ESM). Variability between replicate measurements of the same sample using LC-OCD-OND was assessed by the manufacturer and reported the half confidence interval to be less than $10 \%$ (12.4\% for the neutrals fraction) (DOC-Labor Dr. Huber, Germany).

Total polysaccharide and protein quantification

Polysaccharide and protein were present in similar amounts in EPS extracts and, in most cases, their summation accounted for the measured DOC (Fig. 4). In the August extract, the sum of protein and polysaccharide was greater 
Fig. 2 LC-OCD-OND

chromatograms of periphyton EPS extracts taken between July and December 2011 from 25-day-old biofilms. a For each sample set, upper chromatograms correspond to OC signal and lower to UV absorbance detected at $254 \mathrm{~nm}$. OC and UV chromatograms have different scaling and are not comparable. Integration lines are shown within OC chromatograms. $M_{\mathrm{r}}$ for protein and polysaccharide equivalents generated from calibration curve. b ON signals correspond to biopolymer fractions

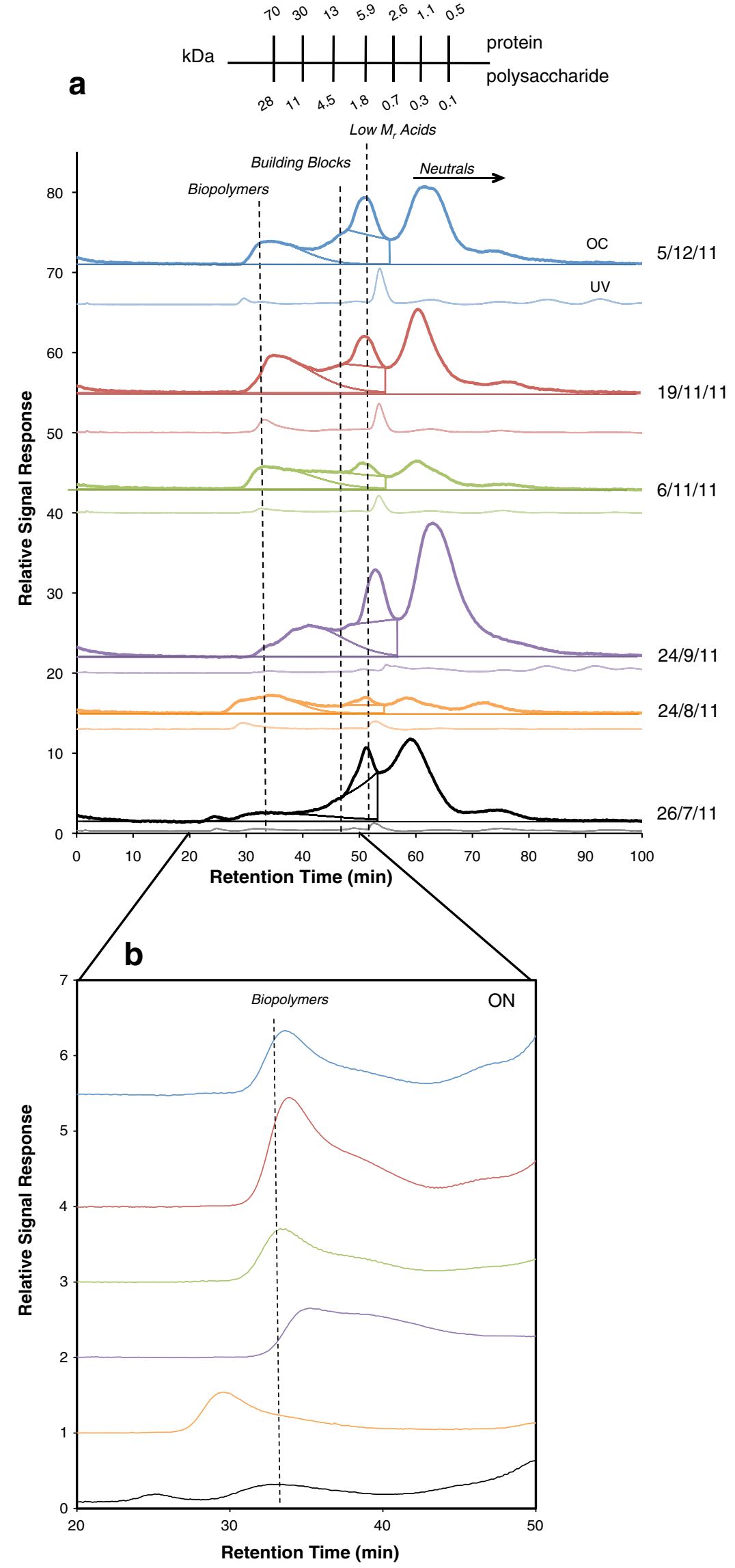




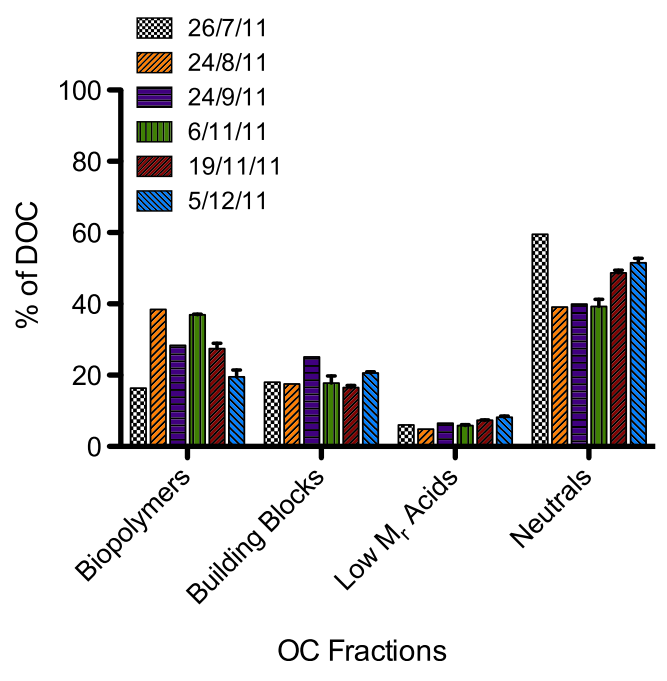

Fig. 3 Quantification of OC fractions from periphyton EPS samples as determined by LC-OCD-OND using the software integration program FIFFIKUS (DOC-LABOR, Germany). Values expressed as percent of chromatographable DOC. Standard deviation bars were generated from replicate extractions performed on the same set of biofilms

than measured DOC. Polysaccharide fluctuated between 0.3 and $1.3 \mathrm{mg} \mathrm{C} / \mathrm{g}$ dry mass and protein between 0.7 and $2.5 \mathrm{mg} \mathrm{C} / \mathrm{g}$ dry mass over the course of study. Additionally, total protein quantified was compared with the biopolymer fraction (Fig. 5). Calculations of $\mathrm{C} / \mathrm{N}$ ratios for the low $M_{\mathrm{r}}$ acid and neutrals fractions were not possible due to the interference of the $\mathrm{NO}_{3}$ signal, and therefore these fractions were not included in the comparison with total protein. The biopolymer fraction ranged from 30 to $67 \%$ of the total quantified protein.

\section{Discussion}

\section{Extraction technique}

As the focus of this work was to obtain an EPS extraction technique suitable for use in future metal-binding studies, a protocol was developed to extract DOC from EPS for

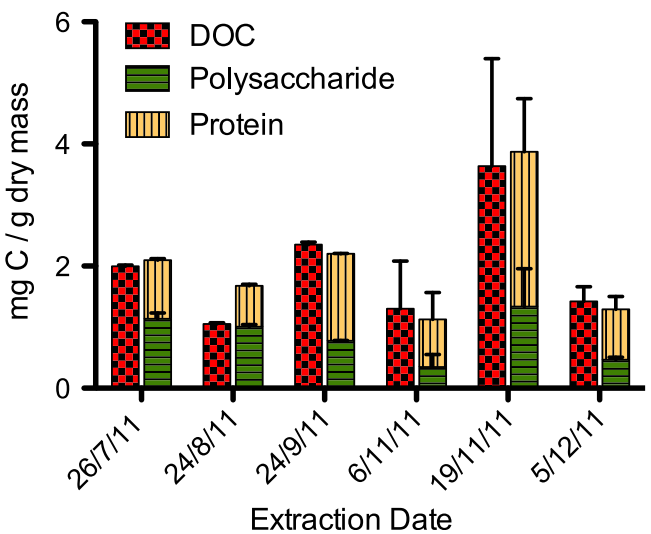

Fig. 4 Comparison of DOC to total protein and polysaccharide from periphyton EPS extracts. Total protein and polysaccharide measured was converted to milligrams of carbon and normalized to lyophilized dry biomass to compare with measured DOC. Standard deviation bars were generated from triplicate measurements

subsequent metal analysis. Because introducing agitation, such as shaking and stirring, as well as longer periods of extraction time, did not increase the extraction efficiency of DOC (Fig. 1), such steps were not included in the extraction protocol. No significant differences in the types of extracted OC compounds were observed between $\mathrm{NaNO}_{3}$ and $\mathrm{NaHCO}_{3}$ extraction solutions (Online resource 3 in the ESM), and, therefore, $\mathrm{NaNO}_{3}$ was chosen to avoid possible formation of metal-carbonate complexes.

It is important to note that the relative amounts of extracted compounds are dependent upon the method of extraction (Liu and Fang 2002; Nielsen and Jahn 1999; Takahashi et al. 2009). Extraction procedures can be physical methods, as used in this study, or chemical methods used to isolate specific types of compounds, whereby either easily extractable soluble compounds, or more tightly bound compounds are extracted, respectively. Soluble compounds include any soluble macromolecules or colloids, whereas the fraction more strongly bound to cell walls of embedded organisms or to other organic material is considered to contain the less easily extracted compounds of the EPS (Nielsen and Jahn 1999). Characterization of the soluble compounds is more commonly reported
Table $1 M_{\mathrm{r}}$ distribution of EPS fractions identified with LC-OCD-OND

Both protein and polysaccharide equivalent $M_{\mathrm{r}}$ ranges calculated for each sample from calibrations generated from globular protein standards and PEG standards and using min and max elution times for each fraction (Online resource 1 in the ESM)

\begin{tabular}{|c|c|c|c|c|c|c|}
\hline \multirow[t]{3}{*}{ Sample } & \multicolumn{2}{|c|}{ Biopolymers } & \multicolumn{2}{|c|}{ Low $M_{\mathrm{r}}$ acids } & \multicolumn{2}{|l|}{ Neutrals } \\
\hline & \multicolumn{6}{|c|}{$M_{\mathrm{r}}(\mathrm{kDa})$} \\
\hline & Protein & Polysaccharide & Peptide & Polysaccharide & Peptide & Polysaccharide \\
\hline 5 December 2011 & $\geq 80-25$ & $\geq 20-9$ & $9-3$ & $3-0.7$ & 3 to $\leq 0.5$ & 0.7 to $\leq 0.5$ \\
\hline 19 November 2011 & $\geq 80-19$ & $\geq 20-7$ & $9-3$ & $3-0.7$ & 3 to $\leq 0.5$ & 0.7 to $\leq 0.5$ \\
\hline 6 November 2011 & $\geq 80-25$ & $\geq 20-9$ & $8-3$ & $3-0.7$ & 3 to $\leq 0.5$ & 0.7 to $\leq 0.5$ \\
\hline 24 September 2011 & $\geq 80-12$ & $\geq 20-4$ & $7-2$ & $2-0.7$ & 2 to $\leq 0.5$ & 0.7 to $\leq 0.5$ \\
\hline 24 August 2011 & $\geq 80-14$ & $\geq 20-4$ & $7-3$ & $2-0.8$ & 2 to $\leq 0.5$ & 0.8 to $\leq 0.5$ \\
\hline 26 July 2011 & $\geq 80-42$ & $\geq 20-15$ & $10-3$ & $3-0.9$ & 3 to $\leq 0.5$ & 0.9 to $\leq 0.5$ \\
\hline
\end{tabular}




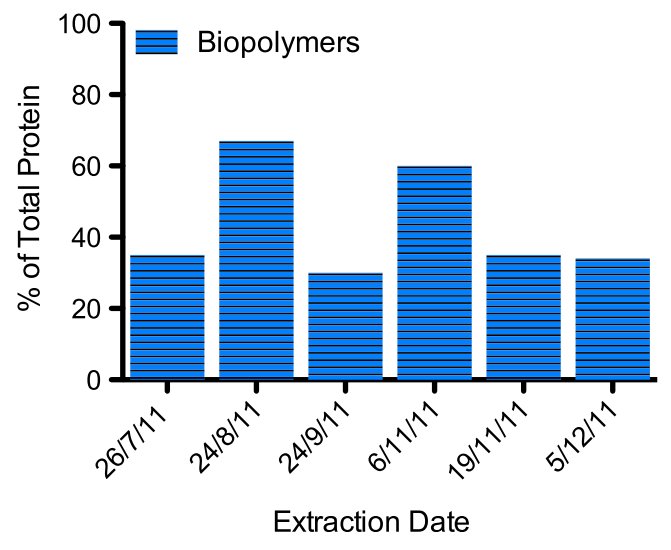

Fig. 5 Comparison of biopolymer fractions to total protein from periphyton EPS. Total protein measured was converted to milligrams of carbon to compare with the biopolymer fraction and biopolymer fraction presented as a percentage of total protein as determined by the Bradford method

in the literature; however, there have also been studies that characterized the more tightly bound fraction (Aguilera et al. 2008; Liang et al. 2010; Sheng et al. 2010). In this study, extracted DOC only reflects OC from soluble and loosely bound EPS. The extraction technique established in this work is suitable when metal speciation is an important consideration. Using sequential chemical extraction techniques can influence properties of the EPS, which can impact metal speciation and produce artifacts (van Hullebusch and Zandvoort 2003). Additionally, using cation exchange resins or EDTA removes metal cations from the EPS (Liang et al. 2010), allowing for the extraction of tightly bound compounds, but also making it difficult to identify specific EPS fractions involved in metal binding.

To assess differences in EPS composition between extracts taken in this study, it was important to determine the variability associated with replicate extractions, which takes into account both the variability associated with biological heterogeneity of the biofilms, as well as that associated with the extraction procedure. Comparison of replicates from extractions performed on two separate occasions showed that the variability is low for DOC and OC compounds over the course of study (Online resource 6 in the ESM). Percent differences between replicates taken in July was less than $10 \%$ for DOC, building blocks, low $M_{\mathrm{r}}$ acids, and neutrals and less than $20 \%$ for biopolymers. In November, percent differences for DOC and biopolymers was less than $5 \%$ and less than $20 \%$ for the remaining compounds. This analysis shows that differences between replicate extracts is low enough to compare differences between extracts over the period of study.

\section{EPS composition}

Biopolymers, building blocks of HS, low $M_{\mathrm{r}}$ acids, and neutral/amphiphilic compounds were identified in all EPS extracts and should only reflect either those compounds excreted from organisms, incorporated from the surrounding water, or released intracellular compounds coming from dying or dead organisms. The extraction procedure itself should not have caused the release of additional compounds, as no detectable amount of cell lysis occurred as a result of extraction (Online resource 4 in the ESM). To date, the majority of work analyzing $M_{\mathrm{r}}$ fractions of EPS comes from bacterial biofilms and there is little work done with EPS from phototrophic biofilms. However, as periphyton are not just comprised of algae, but also contain bacterial communities, the results obtained in this study were compared with the available work conducted with bacterial EPS.

The biopolymer fraction can correspond to high $M_{\mathrm{r}}$ polysaccharides, which are hydrophilic and non-UV absorbing. Al-Halbouni et al. (2008) reported the biopolymer fraction of EPS taken from a membrane bioreactor (MBR) to be mainly composed of polysaccharides and Hong et al. (2012) reported $<1 \%$ of protein in the biopolymer fraction. However, this fraction can also contain amino sugars and proteins. In the present study, the biopolymer fraction was UV absorbing and the $\mathrm{C} / \mathrm{N}$ ratio was more similar to ratios calculated for protein calibration standards $(C / N=0.8-1.1)$ than for PEG standards $(C / N=30-40)$. Therefore, as the $\mathrm{C} / \mathrm{N}$ ratio is influenced by the relative amounts of proteins and polysaccharides, it seems that the biopolymer fraction was largely composed of proteins. In another MBR study, Jiang et al. (2010) also indicated the presence of proteins in the biopolymer peak of soluble microbial products measured in sludge water $(C / N=17-18)$, although less than what was measured in the present study.

The biopolymer fraction contained a range of different $M_{\mathrm{r}}$ proteins, as can be seen by the broad peaks corresponding to this fraction (Fig. 2a). Part of the biopolymer peak contained proteins corresponding to the column separation range (Table 1), while many of these compounds fell within the void volume of the column, corresponding to $M_{\mathrm{r}}$ larger than $80 \mathrm{kDa}$. Resolution of individual proteins within the biopolymer fraction having similar $M_{\mathrm{r}}$ close to the void volume (i.e., BSA and Ovalbumin) was not possible using the OC signal (Online resource 2 in the ESM). Therefore, a column with a higher separation range should be used with LC-OCD-OND for further characterization of the biopolymer fraction.

Studies assessing the $M_{\mathrm{r}}$ distribution of EPS from microbial biofilms have also reported high $M_{\mathrm{r}}$ fractions in similar ranges as found in this study. Simon et al. (2009) observed a fraction corresponding to $32-126 \mathrm{kDa}$ in protein equivalent for anaerobic sludge. Another study investigating the $M_{\mathrm{r}}$ distribution of EPS from activated sludge flocs found two high $M_{\mathrm{r}}$ fractions corresponding to $16-190$ and $270-275 \mathrm{kDa}$ (Comte et al. 2007). Alasonati and Slaveykova (2011) reported specific proteins ranging from 29 to $90 \mathrm{kDa}$ that were identified in EPS from the bacterium Sinorhizobium meliloti and, by using 
asymmetrical flow field-flow fractionation, concluded that a $140-\mathrm{kDa}$ fraction was predominately protein-like substances.

In most extracts, the biopolymer fraction consistently accounted for 30-35\% of the total protein measured using the Bradford assay. This suggests that lower $M_{\mathrm{r}}$ proteins present in the other LC-OCD-OND fractions may contribute to $65-70 \%$ of the total measured protein. It has been observed that peptides down to $3 \mathrm{kDa}$ are detectable using the Bradford assay (Kruger 2002), and therefore, peptides in the low $M_{\mathrm{r}}$ acid fraction should be detected. Assays of individual fractions would be needed to determine protein content in the low $M_{\mathrm{r}}$ acid fraction, as calculation of $\mathrm{C} / \mathrm{N}$ ratios was not possible because of interference of the $\mathrm{NO}_{3}$ signal.

No HS were measured in the EPS extracts, despite being continually measured in the Chriesbach stream water over the course of this 6-month study (data not shown). Liu and Fang (2002) reported humic acids to represent 8.4-30.6\% of extracted EPS from different sludge types, whereas other studies investigating EPS from sludge and wastewater treatment sources cited lower values of 5 and $6.9 \%$ (Frølund et al. 1996; Nielsen and Jahn 1997). A study conducted with periphyton taken from an acidic river showed humic acids to only compose up to $4 \%$ of EPS (Aguilera et al. 2008). The absence of HS in this study is probably because EPS were extracted from newly colonized biofilms after 25 days of growth, and that no HS were incorporated into the EPS from the stream water used to colonize the biofilms. However, building blocks of HS were measured. This fraction, defined as lower $M_{\mathrm{r}}$ break down products of HS (Huber et al. 2011), was most likely not HS degradation products, but rather small organics incorporated from river water or exudates from organisms. Contrary to what was observed in the biopolymer fraction, the more consistent amounts quantified in extracts (Fig. 3) indicate that the compounds within the building block fraction reflected less the changes taking place within the periphyton community over the course of the 6-month study. The percent of building blocks relative to DOC corresponds well with values found by Hong et al. (2012) who reported values between 11.2 and 19.3\% DOC of foulants in a MBR.

The low $M_{\mathrm{r}}$ acid peak, corresponding to final degradation products of organics and products from algal and bacterial excretion, is the sum of all free mono- and diprotic low $M_{\mathrm{r}}$ organic acids. As in the case of building blocks, a narrow $M_{\mathrm{r}}$ range for the low $M_{\mathrm{r}}$ acids was observed and did not display significant changes between July and December (Table 1). In agreement with this finding, Comte et al. (2007) reported that a significant portion of low $M_{\mathrm{r}}$ compounds in EPS extracted from activated sludge were between 0.7 and $2.7 \mathrm{kDa}$. Hong et al. (2012) did not observe low $M_{\mathrm{r}}$ acids; however, Al-Halbouni et al. (2008) presented LC-OCDOND chromatograms with similar percentages of low $M_{\mathrm{r}}$ acid fractions as found in this study.
The low $M_{\mathrm{r}}$ neutral/amphiphilic fraction corresponds to alcohols, aldehydes, ketones and amino acids. This fraction measured in our study was in a similar range as found by Hong et al. (2012), who reported slightly lower amounts (25.1-38.3\% DOC). Interestingly, another group reported that the neutral fraction was only observed in the tightly bound EPS that had been extracted using Dowex cation exchange resin and was not present when only centrifugation was used for extraction (Al-Halbouni et al. 2008).

\section{Applications of LC-OCD-OND in EPS studies}

Information on the $\mathrm{C} / \mathrm{N}$ ratio of the biopolymer fraction could be useful in studying changes in EPS as a result of shifts in species composition from seasonal succession, different stages of biofilm development, or changes in environmental conditions. Changes in extracellular monosaccharide composition of phototrophic biofilms were observed with seasonal changes (D'Souza et al. 2005) and with shifts in community structure (Congestri et al. 2006). A decrease in the total $\mathrm{C} / \mathrm{N}$ ratio, indicating an increase in protein, of EPS extracted from marine biofilms was observed as a function of biofilm age (D'Souza et al. 2005), and specific proteins were identified necessary for bacterial biofilm formation and development (Southey-Pillig et al. 2005). To monitor such changes, LC-OCD-OND could be used as a comprehensive approach that provides more information than total $\mathrm{C} / \mathrm{N}$ ratios and is not limited to the analysis of specific saccharides and proteins, as done using HPLC.

The proteinaceous nature of the biopolymer fraction is also of particular interest with respect to metal binding. A study conducted by Guibaud et al. (2003) showed that proteins were an important contributor to the number of binding sites and overall complexation constants that were determined for $\mathrm{Cd}$, $\mathrm{Cu}$, and $\mathrm{Pb}$. Additionally, it was reported that certain $M_{\mathrm{r}}$ proteins in EPS extracted from periphyton were involved in the binding of $\mathrm{Hg}$ (Zhang et al. 2010) and $\mathrm{Cu}$ (Zhang and Lee 2012). The metal binding ability of EPS and its role in metal toxicity to periphyton is important to investigate, as many studies have measured total metal accumulation and toxicity to periphyton (Ancion et al. 2010; Bradac et al. 2009a, b; Le Faucheur et al. 2005), but less work has been done to understand how metal binding properties of EPS influence metal bioavailability to periphytic organisms. When coupled to metal analysis, LC-OCD-OND could aid in understanding which components of EPS are significant in metal binding.

\section{Conclusions}

The technique LC-OCD-OND is advantageous over other size based fractionation methods as it quantifies both $\mathrm{OC}$ and $\mathrm{ON}$, thus providing additional information about relative amounts of proteins and polysaccharides in different fractions. 
We have developed both polysaccharide and protein calibrations for better $M_{\mathrm{r}}$ determination in LC-OCD-OND and this is the first study to use this technique for analysis of EPS originating from periphyton. We have shown that seasonal variation in EPS composition can be detected and quantified, and that LC-OCD-OND has applications beyond purely chemical characterization. Suggested applications include studies of biofilm community structure and metal-EPS binding. Therefore, we conclude that LC-OCD-OND can be used as a new tool for periphyton EPS characterization to simultaneously identify and quantify OC fractions with respect to protein and polysaccharide content as well as $M_{\mathrm{r}}$ distribution.

Acknowledgments We would like to acknowledge the Swiss National Science Foundation for providing funding for this work as well as the Eawag Werkstatt for their help in the installation of the periphyton colonization flow-through system. We would also like to thank Dr. Marc Suter for internal review of the manuscript.

Open Access This article is distributed under the terms of the Creative Commons Attribution License which permits any use, distribution, and reproduction in any medium, provided the original author(s) and the source are credited.

\section{References}

Aguilera A, Souza-Egipsy V, San Martín-Úriz P, Amils R (2008) Extracellular matrix assembly in extreme acidic eukaryotic biofilms and their possible implications in heavy metal adsorption. Aquat Toxicol 88:257-266. doi:10.1016/j.aquatox.2008.04.014

Alasonati E, Slaveykova VI (2011) Composition and molar mass characterisation of bacterial extracellular polymeric substances by using chemical, spectroscopic and fractionation techniques. Environ Chem 8:155-162. doi:10.1071/EN10119

Al-Halbouni D, Traber J, Lyko S et al (2008) Correlation of EPS content in activated sludge at different sludge retention times with membrane fouling phenomena. Water Res 42:1475-1488. doi:10.1016/j.watres.2007.10.026

Ancion P-Y, Lear G, Lewis GD (2010) Three common metal contaminants of urban runoff $(\mathrm{Zn}, \mathrm{Cu}$ and $\mathrm{Pb})$ accumulate in freshwater biofilm and modify embedded bacterial communities. Environ Pollut 1-8. doi:10.1016/j.envpol.2010.04.013

Bradac P, Behra R, Sigg L (2009a) Accumulation of cadmium in periphyton under various freshwater speciation conditions. Environ Sci Technol 43:7291-7296. doi:10.1021/es9013536

Bradac P, Navarro E, Odzak N et al (2009b) Kinetics of cadmium accumulation in periphyton under freshwater conditions. Environ Toxicol 28:2108-2116. doi:10.1897/08-511R1.1

Bradford MM (1976) A rapid and sensitive method for the quantification of microgram quantities of protein utilizing the principle of protein-dye binding. Anal Biochem 72:248-254. doi:10.1006/abio.1976.9999

Cao B, Shi L, Brown RN et al (2011) Extracellular polymeric substances from Shewanella sp. HRCR-1 biofilms: characterization by infrared spectroscopy and proteomics. Environ Microbiol 13:1018-1031. doi:10.1111/j.1462-2920.2010.02407.x

Celik GY, Aslim B, Beyatli Y (2008) Characterization and production of the exopolysaccharide (EPS) from Pseudomonas aeruginosa G1 and Pseudomonas putida G12 strains. Carbohyd Polym 73:178-182. doi:10.1016/j.carbpol.2007.11.021
Cogan N, Keener J (2004) The role of the biofilm matrix in structural development. Math Med Biol 21:147-166. doi:10.1093/ imammb21.2.147

Comte S, Guibaud G, Baudu M (2007) Effect of extraction method on EPS from activated sludge: an HPSEC investigation. J Hazard Mater 140:129-137. doi:10.1016/j.jhazmat.2006.06.058

Congestri R, Di Pippo F, De Philippis R et al (2006) Seasonal succession of phototrophic biofilms in an Italian wastewater treatment plant: biovolume, spatial structure and exopolysaccharides. Aquat Microb Ecol 45:301-312. doi:10.3354/ame045301

D'Souza F, Garg A, Bhosle NB (2005) Seasonal variation in the chemical composition and carbohydrate signature compounds of biofilm. Aquat Microb Ecol 41:199-207. doi:10.3354/ame041199

DuBois M, Gilles K, Hamilton J et al (1956) Colorimetric method for determination of sugars and related substances. Anal Chem 28:350-356. doi:10.1021/ac60111a017

Esposito S, Guerriero G, Vona V et al (2006) Glucose-6P dehydrogenase in Chlorella sorokiniana (211/8k): an enzyme with unusual characteristics. Planta 223:796-804. doi:10.1007/ s00425-005-0110-2

Frølund B, Palmgren R, Keiding K (1996) Extraction of extracellular polymers from activated sludge using a cation exchange resin. Water Res 30:1749-1758. doi:10.1016/0043-1354(95)00323-1

Guibaud G, Tixier N, Bouju A, Baudu M (2003) Relation between extracellular polymers' composition and its ability to complex $\mathrm{Cd}$, $\mathrm{Cu}$ and $\mathrm{Pb}$. Chemosphere 52:1701-1710. doi:10.1016/S00456535(03)00355-2

Hong S, Aryal R, Vigneswaran S et al (2012) Influence of hydraulic retention time on the nature of foulant organics in a high rate membrane bioreactor. Desalination 287:116-122. doi:10.1016/ j.desal.2011.07.030

Huber SA, Balz A, Abert M, Pronk W (2011) Characterisation of aquatic humic and non-humic matter with size-exclusion chromatography-organic carbon detection-organic nitrogen detection (LC-OCD-OND). Water Res 45:879-885. doi:10.1016/ j.watres.2010.09.023

Jiang T, Kennedy MD, Schepper VD et al (2010) Characterization of soluble microbial products and their fouling impacts in membrane bioreactors. Environ Sci Technol 44:6642-6648. doi: $10.1021 /$ es100442g

Kruger NJ (2002) The Bradford method for protein quantitation. In: Walker J (ed) The protein protocols handbook, 2nd edn. Humana Press, New Jersey, pp 15-21

Le Faucheur S, Behra R, Sigg L (2005) Thiol and metal contents in periphyton exposed to elevated copper and zinc concentrations: a field and microcosm study. Environ Sci Technol 39:8099-8107. doi:10.1021/es050303z

Liang Z, Li W, Yang S, Du P (2010) Extraction and structural characteristics of extracellular polymeric substances (EPS), pellets in autotrophic nitrifying biofilm and activated sludge. Chemosphere 81:626-632. doi:10.1016/j.chemosphere.2010.03.043

Liu H, Fang HHP (2002) Extraction of extracellular polymeric substances (EPS) of sludges. J Biotechnol 95:249-256. doi:10.1016/ S0168-1656(02)00025-1

Meisen S, Wingender J, Telgheder U (2008) Analysis of microbial extracellular polysaccharides in biofilms by HPLC. Part I: development of the analytical method using two complementary stationary phases. Anal Bioanal Chem 391:993-1002. doi:10.1007/s00216-008-2068-y

Meng F, Drews A, Mehrez R et al (2009) Occurrence, source, and fate of dissolved organic matter (DOM) in a pilot-scale membrane bioreactor. Environ Sci Technol 43:8821-8826. doi:10.1021/ es9019996

Navarro E, Robinson C, Behra R (2008) Increased tolerance to ultraviolet radiation (UVR) and cotolerance to cadmium in UVRacclimatized freshwater periphyton. Limnol Oceanogr 53:1149 1158. doi:10.4319/1o.2008.53.3.1149 
Neu T, Lawrence J (2009) Extracellular polymeric substances in microbial biofilms. In: Moran A, Holst O, Brennan P, von Itzstein M (eds) Microbial glycobiology: structures, relevance and applications. Elsevier, London, pp 735-758

Nielsen P, Jahn A (1997) Conceptual model for production and composition of exopolymers in biofilms. Water Sci Technol 36:11-19. doi:10.1016/S0273-1223(97)00318-1

Nielsen H, Jahn A (1999) Extraction of EPS. In: Wingender J, Neu TR, Flemming $\mathrm{H}-\mathrm{C}$ (eds) Microbial extracellular polymeric substances: characterization, structures and function. Springer, Berlin, pp 49-69

Ras M, Lefebvre D, Derlon N et al (2011) Extracellular polymeric substances diversity of biofilms grown under contrasted environmental conditions. Water Res 45:1529-1538. doi:10.1016/ j.watres.2010.11.021

Rouwenhorst RJ, Frank Jzn J, Scheffers WA, van Dijken JP (1991) Determination of protein concentration by total organic carbon analysis. J Biochem Biophys Methods 22:119-128. doi:10.1016/ 0165-022X(91)90024-Q

Sheng G-P, Yu H-Q, Li X-Y (2010) Extracellular polymeric substances (EPS) of microbial aggregates in biological wastewater treatment systems: a review. Biotechnol Adv 28:882-894. doi:10.1016/ j.biotechadv.2010.08.001

Simon S, Païro B, Villain M et al (2009) Evaluation of size exclusion chromatography (SEC) for the characterization of extracellular polymeric substances (EPS) in anaerobic granular sludges. Bioresour Technol 100:6258-6268. doi:10.1016/ j.biortech.2009.07.013

Southey-Pillig CJ, Davies DG, Sauer K (2005) Characterization of temporal protein production in Pseudomonas aeruginosa biofilms. J Bacteriol 187:8114-8126. doi:10.1128/JB.187.23.8114-8126.2005
Stoodley P, Sauer K, Davies G, Costerton J (2002) Biofilms as complex differentiated communities. Annu Rev Microbiol 56:187209. doi:10.1146/annurev.micro.56.012302.160705

Takahashi E, Ledauphin J, Goux D, Orvain F (2009) Optimising extraction of extracellular polymeric substances (EPS) from benthic diatoms: comparison of the efficiency of six EPS extraction methods. Mar Freshw Res 60:1201. doi:10.1071/MF08258

van Hullebusch E, Zandvoort M (2003) Metal immobilisation by biofilms: mechanisms and analytical tools. Rev Environ Sci Biotechnol 2:9-33. doi:10.1023/B:RESB.0000022995.48330.55

Villain M, Simon S, Bourven I (2010) The use of a new mobile phase, with no multivalent cation binding properties, to differentiate extracellular polymeric substances (EPS), by size exclusion chromatography (SEC), from biomass used for wastewater treatment. Process Biochem 45:1415-1421. doi: $10.1016 /$ j.procbio. 2010.05 .018

Zhang D, Lee D (2012) Fluorescent quenching for biofilm extracellular polymeric substances (EPS) bound with $\mathrm{Cu}(\mathrm{II})$. J Taiwan Inst Chem Eng 43:450-454. doi:10.1016/j.jtice.2011.12.010

Zhang D, Pan X, Mostofa KMG et al (2010) Complexation between $\mathrm{Hg}(\mathrm{II})$ and biofilm extracellular polymeric substances: an application of fluorescence spectroscopy. J Hazard Mater 175:359365. doi:10.1016/j.jhazmat.2009.10.011

Zheng X, Ernst M, Jekel M (2009) Identification and quantification of major organic foulants in treated domestic wastewater affecting filterability in dead-end ultrafiltration. Water Res 43:238-244. doi:10.1016/j.watres.2008.10.011

Zippel B, Neu TR (2011) Characterization of glycoconjugates of extracellular polymeric substances in tufa-associated biofilms by using fluorescence lectin-binding analysis. Appl Environ Microbiol 77:505-516. doi:10.1128/AEM.01660-10 